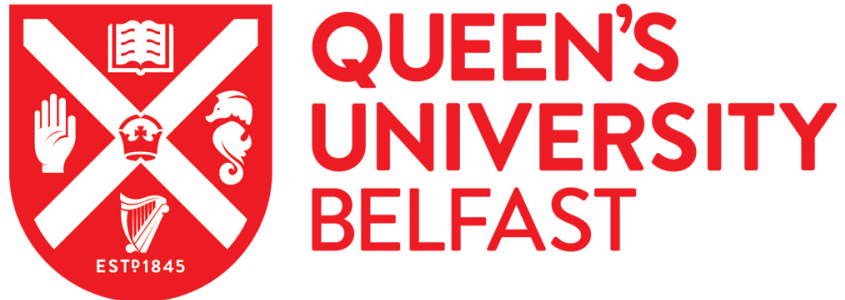

\section{Conceptualising the Role of Consent in the Definition of Rape at The International Criminal Court: A Norm Transfer Perspective}

Dowds, E. (2018). Conceptualising the Role of Consent in the Definition of Rape at The International Criminal Court: A Norm Transfer Perspective. International Feminist Journal of Politics.

https://doi.org/10.1080/14616742.2018.1447311

Published in:

International Feminist Journal of Politics

Document Version:

Peer reviewed version

Queen's University Belfast - Research Portal:

Link to publication record in Queen's University Belfast Research Portal

Publisher rights

Copyright Taylor \& Francis 2017.

This work is made available online in accordance with the publisher's policies. Please refer to any applicable terms of use of the publisher.

\section{General rights}

Copyright for the publications made accessible via the Queen's University Belfast Research Portal is retained by the author(s) and / or other copyright owners and it is a condition of accessing these publications that users recognise and abide by the legal requirements associated with these rights.

Take down policy

The Research Portal is Queen's institutional repository that provides access to Queen's research output. Every effort has been made to ensure that content in the Research Portal does not infringe any person's rights, or applicable UK laws. If you discover content in the Research Portal that you believe breaches copyright or violates any law, please contact openaccess@qub.ac.uk. 


\title{
Conceptualising the Role of Consent in the Definition of Rape at The International \\ Criminal Court: A Norm Transfer Perspective
}

\begin{abstract}
Over the past three decades' international criminal legal standards on sexual and gender-based violence (SGBV) have developed rapidly, sparking debate within feminist circles over the extent to which these developments might bear relevance to domestic contexts in a process termed “norm transfer." Indeed, non-governmental organisations and feminist scholars have called for domestic adoption of the International Criminal Court (ICC) definition of rape due to its omission of the element of the absence of consent. However, the place of consent in an international criminal definition of rape is a hotly contested topic, with disagreement as to whether rape in conflict should be considered "exceptional” or a continuation of everyday violence against women. This article provides a new lens from which to explore these questions by situating the feminist strategy of norm transfer within the complementarity-based system of the ICC. It uncovers a number of gaps within the ICC definition that raise questions not only about the status of the definition as a candidate for norm transfer but also about the robustness of the definition in and of itself. It concludes by considering the role of consent as an implicit element within the ICC definition and its operation as a defence.
\end{abstract}

Key words: International Criminal Court, Complementarity, Norm Transfer, Rape, Consent. 


\section{INTRODUCTION}

Over the last three decades, feminist presence in international criminal law (ICL) has grown substantially (Chinkin 1994; Halley, 2008; Ní Aoláin 2015), forming part of what Chappell has conceptualised as the "feminist international law project" $(2016,9)$. While this "project" is not singular, as it is made up of a "mosaic of feminist interventions and positioning’s” (Ní Aoláin 2015, 457), a significant part of this project has been securing the criminalisation of sexual and gender-based violence $(\mathrm{SGBV})^{1}$ perpetrated against women in times of conflict (MacKinnon 1994; Askin 2003; Chappell 2016). ${ }^{2}$ Concrete evidence of these efforts can be found in dialogue between feminists and staff at various international criminal judicial bodies via amicus briefs (Green et al 1994; Chinkin 1995; Copelon 2000-01; Halley 2008), and in the articulation of SGBV in the statutes and jurisprudence of bodies such as the ad hoc Tribunals in Rwanda (ICTR) and the former Yugoslavia (ICTY), and the International Criminal Court $(\text { ICC })^{3}$ (Bedont and Hall Martinez 1999; Halley 2008).

Feminist engagement with ICL is, however, a contradictory site (Kouvo and Pearson 2011; Chappell and Durbach 2014) and there are different expectations as to what ICL can offer women, both inside and outside of conflict (Grewal 2010; Spees 2013). Indeed, the desire to secure "norm transfer," the proposal that international criminal standards on SGBV trickle down to the national level, can be found within early feminist scholarship (Green et al, 1994; Ní Aoláin 1997; Kuo 2002; O’Rourke 2013, 24) raising questions over the extent to which SGBV in conflict can be considered "exceptional "or a continuation of everyday violence (Copelon 2000-01; Wood 2014; Grewal 2015; Meger 2016). This debate is prominent in the context of defining the crime of rape in ICL, with conflicting views as to the appropriate role of consent within this definition (De Brouwer 2005; Grewal 2010 and 2015). 
While rape is a global phenomenon (García-Moreno et al 2013, 2), it has been suggested that rape in conflict occurs with greater frequency and intensity than in peacetimes (Hagen 2010, 15; Cohen 2013). This is evidenced by the high levels of rape committed during some conflicts (United Nations Secretary General 2017); the high level of multiple perpetrator rapes in conflict settings as compared to peacetime settings ${ }^{4}$ (Horvath and Woodhams 2013, 2; Cohen 2013, 399; Wood 2014, 464); the brutal means through which rape is perpetrated during conflict (O’ Byrne 2011, 511; Wood 2014, 464); and the relationship between the victim and perpetrator: many armed combatants do not know their victims whereas most victims of peacetime rape are abused by current or former partners ${ }^{5}$ (García-Moreno et al 2013, 16-20). Attention has also been drawn to the system of organised violence within which rape occurs in conflict (Boon 2001, 631; O’Byrne 2011, 511).

Despite these differences, there have been calls for the domestic adoption of the ICC definition of rape due to its omission of the element of absence of consent (Spees 2003; Amnesty International 2005). This article enters the conversation by situating the feminist strategy of "norm transfer" within the complementarity-based system of the ICC and applying this new lens to the controversy surrounding the place of consent in the ICC definition of rape. I uncover a number of gaps within the definition that raise questions not only about the status of the definition as a candidate for norm transfer but also about the robustness of the definition in and of itself. I conclude by considering the role of consent as an implicit element within the ICC definition and its operation as a defence.

\section{NORM TRANSFER AS A FEMINIST STRATEGY AND THE ROLE OF THE ICC}

In exploring how the strategy of norm transfer might be activated, feminist attention has recently been directed towards the ICC and its complimentary regime (Ní Aoláin 2014; Kapur 2016, 67). As the analysis below will demonstrate, the complementarity regime of the ICC may 
facilitate the process of norm transfer in two stages: the first stage involves transposing international norms into domestic law on international crimes and the second stage involves filtering these norms into domestic law or practice on domestic crimes.

\subsection{Norm-Transfer in Two Stages: Utilising Complementarity}

The complementarity regime of the ICC provides that the Court only steps in where a State is "unwilling or unable" to genuinely carry out the investigation or prosecution of those alleged to be responsible for crimes under its Statute (Article 17(1)). The Office of the Prosecutor (OTP) has adopted a positive approach to complementarity, meaning it "encourages genuine national proceedings where possible; relies on national and international networks; and participates in a system of international cooperation” (ICC-OTP 2006). Therefore, a key feature of complementarity is to encourage States to incorporate the ICC Statute into their national legislation; this requires the adoption of implementing legislation, such as The United Kingdom International Criminal Court Act 2001.

While there is no legal obligation for States to adopt the ICC Statue in its entirety, substantial normative support for the domestic adoption of certain core aspects of the Statute can be found in academic literature and soft law sources. De Brouwer, for instance, has suggested that States incorporate the general content of the ICC Statute into domestic law and also its legislation and procedural rules on crimes of sexual violence (2009, 202): the first stage of norm transfer. Similarly, the OTP's 2014 Policy Paper on Sexual and Gender-Based Crimes encourages State Parties to adopt the legislation and procedures on SGBV domestically to reinforce the normative framework of the ICC and facilitate effective prosecution (paragraph 105). Thus, the first stage of norm transfer is in the form of a legislative transfer.

Furthermore, it has been suggested that the ICC has the potential to significantly impact domestic law on domestic crimes: the second stage of norm transfer. As noted by Spees, the 
gender provisions of the ICC Statute could "help strengthen the capacity to address violence against women at the national level via the inclusion of additional crimes of sexual and gender violence, progressive definitions of existing crimes, and more gender-sensitive procedures for the trial of these crimes” (2003, 1246). Indeed, in 2005, Amnesty International developed a practical tool for non-governmental organisations in which it encouraged them to use the "the process of implementation of the Rome Statute at the national level to address weaknesses in their existing laws relating to violence against women” (7). In this regard, the second stage of norm transfer is more of a trickle down process, giving domestic actors the opportunity to rethink existing law and prompt change.

An example of the Rome Statute providing the impetus for change can be seen in the Democratic Republic of the Congo (DRC), with one organisation stating that, "there have been changes brought by the ICC statute [in how the law deals with gender based violence]. This is the case with the new law on rape and sexual violence in the DRC of 2007 which brings new characterisation of acts of rape and sexual violence” (Victim’s Rights Working Group 2010, 207). In light of the potential for the ICC legal instruments to have influence beyond the narrow confines of ICL it is necessary to explore the desirability of this relationship further.

\subsection{Is Norm Transfer Desirable?}

The value of the first stage of norm transfer is relatively uncontroversial. While ICL is not a homogeneous system and norm creation occurs at a largely decentralized level, the ICC and its foundational documents have been commended for their uniformity; thus, bringing some order to ICL (Gekker 2014). Encouraging harmonisation between legislation at the international criminal level and the domestic level on international crimes will contribute to this uniformity, promoting legal consistency, coherency and certainty. 
The second stage of norm transfer, on the other hand, is more complicated. ICL and domestic criminal law are distinct from one another. As noted in the Preamble to the Rome Statute, war crimes, crimes against humanity and genocide represent "unimaginable atrocities that deeply shock the conscience of humanity.” These crimes transcend individual suffering and possess a collective feature which is reflected in their substantive definitions through the inclusion of a “common element” (Marcus 2013, 13). According to the Rome Statute, SGBV will amount to genocide only when committed with the "intent to destroy, in whole or in part, a national, ethnical, racial or religious group” (Article 6); a crime against humanity when committed "as part of a widespread or systematic attack directed against any civilian population” (Article 7); and a war crime when committed "as part of a plan or policy or as part of a large-scale commission of such crimes" (Article 8). These crimes are often categorised as "exceptional” (Fisher 2012, 49) raising questions over the desirability, and indeed appropriateness, of norm transfer between the international and domestic.

Yet, SGBV is not exceptional in the sense that it only occurs in situations of conflict or mass violence: indeed, this violence is perpetrated both in times of peace and conflict. As formulated by Charlesworth and Chinkin, violence against women in conflict and peace "are not distinct phenomena but form part of the same spectrum of behaviour. They are both the product of systematic relations of male power and domination” $(2000,64)$. Charlesworth and Chinkin are drawing attention to the broader discriminatory system within which violence against women takes place, a system that exists in both forums (Brammertz and Jarvis 2016, 386). Indeed, the gendered politics that subordinate, objectify and silence women in peacetime, contribute to the construction of women's bodies as sexually available and vulnerable rendering rape and sexual violence effective tools of war (Bergoffen, 2009, 315-18). While the context and manifestation of SGBV may differ when perpetrated in conflict or peace - and it is necessary to recognise these differences for the purpose of accountability and jurisdiction - characterising the former 
instances of SGBV as "exceptional" fails to acknowledge the continuum of violence experienced by women (Grewal 2010, 77).

In light of this, I would argue that the contextualisation of SGBV in ICL, i.e., situating it within a broader attack or strategy of violence, should not be used as means to dichotomise such violence in conflict and peace, rather it should provide the impetus to contextualise SGBV perpetrated at all times. Viewed in this way, we begin to see the value of the second stage of norm transfer: a new way of thinking can be applied to SGBV perpetrated in peace that may expose broader systems of oppression. The next section will explore the second stage of norm transfer in more detail.

\section{FACILITATING THE SECOND STAGE OF NORM TRANSFER: DEFINING RAPE}

Defining the crime of rape in ICL has been a controversial task, providing a unique space from which to deploy and test the second stage of norm transfer. As will be demonstrated below, there has been varying engagement with domestic law highlighting the circular nature of norm transfer: domestic - international - domestic. Consequently, four overlapping, though distinct, definitions of rape have been constructed: three at the ad hoc Tribunals and one contained within the 'Elements of Crimes' for the ICC. The latter definition in particular has captured the attention of various non-governmental organisations and scholars, with Amnesty International asserting that, "National definitions of rape will be improved and will be in compliance with international standards by following this definition” (2007). A key feature of the ICC definition is that it omits explicit reference to the absence of consent and this has been viewed by many as representing a more robust alternative to domestic definitions (Munro 2010; Chappell 2016).

In the domestic realm, proving that the complainant did not consent and the defendant's knowledge of that fact, are often the key and most controversial issues in rape cases (United Nations Commission on Human Rights 1994, 42; Rt Hon Dame Elish Angiolini 2015, 10). In 
this regard, Temkin and Krahe, have criticized the reliance on social conventions in interpreting consent or lack thereof: "no other criminal offence [...] is as intimately related to broader social attitudes and evaluations of the victim's conduct as sexual assault” (2008, 33). Consequently, there is often an undue focus on the behaviour of the complainant, as opposed to the conduct of the perpetrator, tainted by myths and stereotypes surrounding the "ideal" victim of rape with expectations of serious physical harm and signs of resistance (Gotell 2008, 878). Indeed, in cases where the victim and perpetrator are known to one another, proving absence of consent is notoriously difficult (McGregor 2005).

It is assumed that questions of consent and related stereotypes are harder to raise in the international criminal context, due to the "horrific external circumstances" of international crimes (Grewal 2010, 64). Yet, despite the explicit omission of consent from the ICC definition, the issue has re-emerged in cases and there remains a lack of clarity around the role of consent: do the existing elements in the definition constitute evidence of lack of consent or do they operate independently from consent? The current uncertainty around these issues raise core substantive questions of criminal law that must be resolved before any consideration of norm transfer can occur.

\subsection{Defining Rape: The Controversy around Consent}

The Elements of Crimes definition of rape for the ICC was finalised by the Preparatory Commission in 2000, who were mandated to draw up a text to assist the ICC judges in the interpretation and application of the crimes under its Statute. In drafting the definition, the Commission had the benefit of the Akayesu ${ }^{6}$ and Furundžija ${ }^{7}$ definitions which were developed at the ICTR and ICTY, respectively, in 1998. Rape was defined in Akayesu as "a physical invasion of a sexual nature, committed on a person under circumstances that are coercive.” ${ }^{8}$ In Furundžija, following a survey of 18 national jurisdictions, the ICTY provided a more mechanical account of rape centred around penetration, as opposed to "invasion", requiring the 
use of "coercion or force or threat of force against the victim or third person." 9 The methodology used by the ICTY is noteworthy: the court drew from domestic definitions of rape to identify general principles of law, concluding that "most legal systems in the common and civil law worlds" consider rape to be forcible sexual penetration. ${ }^{10}$ Interestingly, neither definition makes explicit reference to consent. Furthermore, according to Rule 96 of the Rules of Procedure and Evidence, shared by both Tribunals, consent would not be allowed as a defence if the victim or another person had been subject to or made to fear violence, duress, detention or psychological oppression. ${ }^{11}$

The Elements of Crimes definition for the ICC incorporates elements from the above definitions as well as Rule 96 in its definition, providing that the crime of rape is established where the prohibited conduct was committed "by force, or by threat of force or coercion, such as that caused by fear of violence, duress, detention, psychological oppression or abuse of power, against such person or another person, or by taking advantage of a coercive environment, or the invasion was committed against a person incapable of giving genuine consent." ${ }^{2}$ The reference to "genuine consent" is accompanied by a footnote providing that "a person may be incapable of giving genuine consent if affected by natural, induced or agerelated incapacity.” ${ }^{13}$ Consent is retained as a defence in Rule 70 of the Rules of Procedure and Evidence for the ICC, which, in contrast to Rule 96 for the ad hoc Tribunals, provides only that consent may not be inferred from the words or conduct of the victim where force, threat of force, coercion or taking advantage of a coercive environment undermined the victim's ability to give voluntary and genuine consent. ${ }^{14}$ This wording suggests the circumstances contained in the definition amount to rebuttable presumptions against consent and that consent may be raised as a defence, although subject to strict evidential rules including the requirement to hold an in camera hearing. ${ }^{15}$ 
In 2001, a year after the Elements of Crimes definition, a fourth definition was constructed at the ICTY in the case of Kunarac. ${ }^{16}$ Following a survey of 37 national jurisdictions, the Court altered the legal landscape by requiring that the prohibited conduct "occur without the consent of the victim.” ${ }^{17}$ In conceptualising rape as a violation of sexual autonomy, the Trial Chamber asserted that the Furundžija definition was too narrowly stated and that the definition should be broadened to include other factors, beyond force or coercion, that might "render an act of sexual penetration non-consensual or non-voluntary on the part of the victim." 18 Thus, the Chamber attempted to capture the essence of the crime - the violation of sexual autonomy and construct a definition capable of capturing the different ways in which that violation can manifest. The Chamber defined consent as “consent given voluntarily, as a result of the victim’s free will, assessed in the context of the surrounding circumstances,” and the Appeal Chamber clarified the boundaries of consent noting that "the circumstances...that prevail in most cases charged as either war crimes or crimes against humanity will be almost universally coercive. That is to say, true consent will not be possible." ${ }^{19}$ Subsequent cases at the ad hoc Tribunals followed this approach, providing that any form of coercion or generally oppressive surrounding circumstances amounted to evidence of lack of consent and that absence of consent may be inferred from these circumstances. ${ }^{20}$

Following Kunarac there was uncertainty as to whether the ICC would embrace or reject the absence of consent approach taken at the ICTY when interpreting the Elements of Crimes definition (O’Byrne 2011, 513; Henry 2014, 102). In line with the exceptionality arguments outlined above, the ICTYs approach was criticised by many for applying "peacetime law in a wartime trial” (Kalosieh 2003, 132; Schomburg and Peterson 2007; O’Byrne 2011). Others, however, argued that the focus on coercion as opposed to consent denies women's sexual agency during war (Engle 2005, 803; Halley 2008). According to Grewal, the ICTY struck the appropriate balance in Kunarac by acknowledging the coerciveness of the situation without 
completely removing the possibility of agency and choice (2015, 162). Grewal also criticised the creation of a dichotomy between rape in conflict and rape in peace which reinforces a "fantasy of equal autonomy" outside of conflict, and forecloses any possibility of a broader conversation about the "many different conditions of inequality within which women (and, in some cases men) often negotiate sex” $(2015,156)$.

The ICC confirmed its position in the cases of Katanga and Bemba in 2014 and 2016 respectively, stating in no uncertain terms that "The victim's lack of consent is not a legal element of the crime of rape under the Statute.”21 The Trial Chamber provided that where force, threat of force or coercion, or taking advantage of coercive environment are proven, the Prosecution does not need to prove the absence of consent. However, it provided no specific guidance on role of consent as a defence under Rule 70. This interpretation has been welcomed by Clark: “it treats circumstances as set out in the ICC's Elements of Crimes as important in their own right, rather than in the more limited sense of whether they vitiate consent” (2016, 677). On Clarks reading, the elements contained in the definition are not evidence of the absence of consent and thus rape, rather they are constitutive of rape. In detaching the circumstances contained within the definition from consent the ICC has potentially created the "space for a greater focus on what the victim experienced within the context of that environment” (Clark 2016, 677). While the ICC is to be commended for decentring the notion of consent where abusive factors are present, it will be argued below that the ICC's interpretation remains problematic.

\subsection{The ICC Definition: An Alternative Approach?}

In light of the criticisms of consent within domestic definitions of rape, the ICC's approach may seem attractive: it responds to domestic feminist concerns by de-centring the problematic notion of consent. Furthermore, the element of a coercive environment provided in the definition may add substantially to domestic definitions of rape by contextualising the crime. 
Indeed, such an element was incorporated into the new law in the DRC, noted above, defining rape as sexual abuse "using violence or intimidation, either directly or through an intermediary, including by using psychological pressure or by means of a coercive environment." 22 The inclusion of the latter element may capture situations of "survival consent” (Pearce 2013, 63), where individuals are faced with little or no alternatives and give apparent consent in the context of severe poverty, familial or intimate abuse, economic oppression or other forms of domestic violence. Attention is thus directed towards the complex relationship between individual agency and coercion emanating from external circumstances, as opposed to individual acts, that can have a direct impact on the ability to make choices and give meaningful consent.

However, attention must be paid to the unintended consequences of adopting the ICC approach to rape in the domestic context. In commenting on the new DRC definition, for instance, the International Federation for Human Rights (IFHR), a non-governmental organisation, stated that "it is the use of violence, and not the lack of consent by the victim that becomes the main element in proving rape. This is in line with recent international practice” (2013, 42). The suggestion that the focus on violence is in line with international practice is problematic in light of the central role given to consent in international human rights standards on rape. In the 2003 case of M.C $v$ Bulgaria, for instance, the European Court of Human Rights asserted that respect for sexual autonomy is key, and that there is "a universal trend towards regarding lack of consent as the essential element of rape.” ${ }^{23}$ The Court noted the need to move away from "rigid" approaches to rape that centre on force or resistance. The Council of Europe has taken a similar stance noting that where rape is defined in terms of force, States are required to interpret the definition in a way that encompasses the notion of a lack of freely given consent. ${ }^{24}$ 
While consent can be problematic in the context of rape, the need for its retention in domestic definitions cannot be underestimated in light of the tendency of courts to interpret terms such as force and coercion narrowly (Munro 2010, 26). This is evidenced in the case of RPB $v$ the Philippines, before the Committee on the Elimination of Discrimination against Women, where the Regional Trial Court of Pasig City acquitted the accused of rape on the basis of a number of problematic principles derived from the Supreme Court:

No physical force was used to quell R.’s alleged resistance. Her mouth was not covered nor stuffed with any object. Except for the alleged pulling of her arms, struggling and showing that she was already angry, the prosecution failed to prove that R.'s movement was physically restrained [...] Even if her arms were pulled, she was not threatened with bodily or physical harm [....$^{25}$

Thus, a focus on force, coercion, or other factors may be regressive, ultimately reinforcing problematic historical understandings of the crime of rape where only sexual penetration accompanied by force or coercion is viewed as “real” rape (Estrich 1987).

Furthermore, the above analysis would suggest that the ICC's assertion that the absence of consent is not a legal element of its definition is in contravention of Article 21 (3) of its Statute requiring that the law applied by the Court is consistent with human rights standards. Indeed, it could be argued that the ICC is obliged to acknowledge the absence of consent as an implicit element of the definition. However, the Court has failed to do so, leading some to conclude that the elements contained in the definition are completely separate to any issues of consent (Clark 2016). Thus, on a principled level, the ICC definition is only partially representative of the ways in which the crime of rape may be perpetrated. The definition accounts for situations where there is force, threats, taking advantage of a coercive environment or where an individual is incapacitated and incapable of giving genuine consent; yet, in contrast to the definition of 
enforced sterilization, as contained within the Elements of Crimes, it fails to account for instances of rape by deception, ${ }^{26}$ and, further, it fails to capture situations where an individual is untouched by any of these elements and simply does not want to have sexual intercourse with the individual in question.

The foregoing argument may be resisted on the basis that the criminal law is primarily concerned with the liability of the perpetrator, which in the context of ICL often involves overt coercion or violence, and should thus not be concerned with the state of mind of the victim (Erez and Sebba, 2013: 189). Moreover, it may be argued that the Elements of Crimes definition was designed with the specific purpose of prosecuting rape as an international crime; as such it should not be tampered with on the basis that it fails to capture all of the ways in which rape may manifest or that it may result in narrow interpretations of rape at the domestic level. In response it is suggested that any definition of rape, whether international or domestic, should reflect the essence of the crime. In the case of rape, human rights bodies and the ICTY have declared that essence of rape is the violation of sexual autonomy, requiring "the penalisation and effective prosecution of any non-consensual sexual act.”27

Furthermore, on a practical level, the issue of consent has re-emerged during trial proceedings. This is evidenced in Bemba, where, following the testimony of a male victim of rape in which he recounted his own rape by three armed soldiers, that of his wives and his daughters, one of whom was 11 at the time, the Prosecution asked: “Did you consent to this act?”; "Did your daughters consent to these rapes?.”28 The judgment also refers to one witness having "stated that she had recently given birth, thus expressing lack of any consent."29 Thus, the issue of consent continues to be considered during legal proceedings, yet there is no formal legal standard against which the Prosecution or Judiciary are to consider evidence of consent: the Elements of Crimes only make reference to "genuine consent" in the context of incapacity and 
do not provide a mens rea element for consent; similarly Rule 70 of Procedure and Evidence provides no definition of consent as a defence. International criminal legal actors are therefore relying on their own understanding of consent which will be influenced by their diverse cultural, social, educational and professional backgrounds. This is particularly problematic from a substantive criminal law perspective which requires the law to be clear, accessible and unambiguous (Shahabuddeen 2004).

Thus, it can be concluded that the ICC definition, in its current form, does not provide a suitable alternative to consent centred domestic definitions. Furthermore, applying the lens of norm transfer to this definition uncovers a number of gaps that raise questions not only about the status of the definition as a candidate for norm transfer but also about the robustness of the definition in and of itself. The next section rethinks the definition of rape at the ICC with a view to clarifying the role of consent. This exercise will not only result in a more robust definition at the international criminal level, it will also help to prevent the reinforcement of narrow and regressive interpretations at the domestic level.

\subsection{Rethinking the Definition of Rape at the ICC and the Role of Consent}

In order to overcome the principled challenges associated with the definition, the ICC should explicitly articulate and endorse the absence of consent as an implicit element of the definition in future prosecutions. The benefit of this endorsement is twofold: firstly, it ensures an interpretation of the definition that is consistent with Article 21 (3) of the Rome Statute; secondly, it broadens the capture potential of the definition to include instances other than force or violence that may render sexual activity non-consensual, such as deception for example.

To overcome the practical challenges, the ICC should provide a clear definition of consent to ensure consistent interpretation by international criminal legal actors. In this regard, the Court may find the language of consent in Kunarac helpful: "Consent for this purpose must be 
consent given voluntarily, as a result of the victim's free will, assessed in the context of the surrounding circumstances.” 30 This definition opens up the space to articulate the different ways in which the crime of rape undermines the free will of the victim and provides a clear legal standard against which aberrations and other potential instances of rape can be exposed, leading to consistency and clarity in the law. Furthermore, the inclusion of a positive, contextual, definition of consent is reflective of broader practice in domestic and human rights law where consent is defined using nuanced language that recognises and respects individual agency (Grewal 2012, 383; Munro 2017).

If the Court were to endorse consent as an implicit element and provide a definition it would then be required to provide clarification as to how this element interacts with the existing elements of the definition and with consent as a defence under Rule 70. The existing elements of the definition include force, threat of force or coercion, such as that caused by fear of violence, duress, detention, psychological oppression or abuse of power, against such person or another person, or by taking advantage of a coercive environment, or the invasion was committed against a person incapable of giving genuine consent. Examining these elements in light of the positive definition of consent noted above, these are instances that have the effect of undermining or constraining freewill; thus, the absence of consent should be presumed and need not be independently proven. Indeed, the ICC has already stated that the prosecution need not prove consent in these circumstances.

More clarity is however required in relation to when consent may be entertained as a defence under Rule 70 where any of the circumstances listed in the definition are present (Boon 2001; Grewal 2012). In this regard, consideration should be given to whether a conclusive presumption against consent may be warranted in some circumstances as opposed to a rebuttable presumption. Take for example the reference to an individual being incapable of genuine consent, we know from the footnote that this refers to incapacity: where an individual 
is incapacitated their consent cannot be "voluntary" or the result of "freewill," thus a conclusive presumption against consent would be appropriate. A conclusive presumption would also be justified where the victim is detained by the perpetrator; indeed, many domestic jurisdictions apply strict liability in these circumstances due to the stark imbalance of power between the parties. ${ }^{31}$ Where the perpetrator is not responsible for the detention of the victim, a rebuttable presumption would suffice as, depending on the specific circumstances, while voluntariness or freewill will be constrained they may not be completely diminished.

The presumptions to be imposed in relation to the categories of coercion set out in the definition are more difficult to determine as the court is yet to fully specify the boundaries of these categories. For example, it is unclear whether the fear of violence, duress, or psychological oppression experienced by the victim had to be caused by the accused or whether it could be generalised fear based on the situation in the country or region. Imposing a conclusive presumption on the basis of a generalised fear may be too far reaching and leave little space to recognise the highly strategic decisions made by women in oppressive situations (Engle 2005). A rebuttable presumption on the other hand would help to identify instances of "survival consent” in which choices are substantially constrained due to the environment (Pearce 2013, $63)$.

Where a rebuttable presumption is maintained the defence may raise the issue of consent, in accordance with the strict evidential rules of the Court. However, the definition of consent noted above, ensures that any defence of consent is contextualised. Furthermore, the Court may wish to interpret the phrase "in the context of the surrounding circumstances" as imposing a requirement on the accused to demonstrate any steps taken to ensure the victim was consenting. This requirement need not be controversial as Grewal has drawn attention to such positive obligations placed on defendants in many domestic definitions of rape and the move to consent being something actively sought rather automatically assumed (2012, 387-388). 
The suggestions put forward here, would result in a more robust definition of rape and ensure clarity and consistency in its application. The definition would also take on new significance from a norm transfer perspective, as it would not only expand our understanding of the ways in which the crime of rape may manifest i.e., coercive circumstances, it would also encapsulate good practice in relation to consent by adopting a more nuanced and contextual understanding of the concept. Domestic actors looking to the international for inspiration may then be less likely to interpret the definition as focusing on violence.

\section{CONCLUSION}

Feminist intervention into ICL, and the feminist strategy of norm transfer, have brought to the fore key debates surrounding the extent to which ICL and domestic criminal law should converge. The feminist strategy of norm transfer, however, is based on the premise that violence against women transcends the boundaries between the international and the domestic; as such, in line with the second stage of norm transfer, developments at the international criminal level can help to inform domestic criminal law on SGBV. Indeed, many scholars and activists have sought to activate this process of norm transfer through the complimentary regime of the ICC. Thus, the legal instruments of the ICC have the potential to make a significant contribution to the way SGBV is understood across the globe.

In evaluating the definition of rape contained within the Elements of Crimes for the ICC in light of the feminist strategy of norm transfer, this Article has provided a new lens from which to consider the appropriate role of consent within the definition. If the feminist project in international law aims to improve the lives of women, whether in times of conflict or in times of peace, the relevance of consent as an implicit element within the ICC definition should be endorsed, rather than rejected, and a nuanced conversation about the way in which consent as a defence interacts with force, coercion and other instances of oppression should be encouraged. 
${ }^{1}$ The Office of the High Commissioner for Human Rights defined Gender-based violence as "any harmful act directed against individuals or groups of individuals on the basis of their gender”. Sexual violence is one form of gender-based violence and includes any act of a sexual nature that results, or is likely to result in, physical, psychological and emotional harm: "Sexual and gender-based violence in the context of transitional justice” 2014 available at http://www.ohchr.org/Documents/Issues/Women/WRGS/OnePagers/Sexual_and_genderbased_violence.pdf [last accessed 15/08/2017]

${ }^{2}$ While SGBV is also committed against men, see for instance Sivakumaran, S. 2007. 'Sexual Violence Against Men in Armed Conflict' The European Journal of International Law 18(2): 253-276, research has shown that women are more frequently victimised in this way and ICL has been slow to respond: J.G. Gardam and M.J. Jarvis, Women, Armed Conflict and International Law (Kluwer Law International, 2001).

${ }^{3}$ Statute of the International Tribunal for the Prosecution of Persons Responsible for Serious Violations of International Humanitarian Law Committed in the Territory of the Former Yugoslavia since 1991, U.N. Doc S/25704 at 36, annex (1993) and S/25704/Add.1 (1993), adopted by Security Council on 25 May 1993, U.N. Doc S/RES/827 (1993); Statute of the International Tribunal for Rwanda, adopted by S.C. Res. 955, U.N. SCOR, 49th Sess., 3453d mtg. at 3, U.N. Doc S/RES/955 (1994), 33 I.L.M. 1598, 1600 (1994); Rome Statute for the International Criminal Court, 17 July 1998, 2187 UNTS 90, entered into force 1 July 2002. ${ }^{4}$ According to Cohen 2013, in Sierra Leone, 76\% of conflict-related rapes of women in Sierra Leone were by multiple perpetrators. According to Horvath and Woodhams, 2-27\% of rapes carried out in peacetime contexts are multiple perpetrator rapes.

${ }^{5}$ According to García-Moreno et al, worldwide, almost one third (30\%) of all women who have been in a relationship have experienced physical and/or sexual violence by their intimate 
partner; globally, as many as 38\% of all murders of women are committed by intimate partners; globally, $7 \%$ of women have been sexually assaulted by someone other than a partner. Note however that in some cases of conflict rape the victim and perpetrator are known to one another (Hagen 2010, 18).

${ }^{6}$ Prosecutor v. Akayesu, Case No. ICTR-96-4-T, Judgment (Sept. 2, 1998).

${ }^{7}$ Prosecutor v Furundžija, Case No. IT-95-15/1, Judgement (Dec. 10 1998)

${ }^{8}$ Akayesu, paragraph 598.

${ }^{9}$ Furundžija, paragraph 180-185. Jurisdictions surveyed by the Tribunal included: Chile, China, Germany, Japan, Yugoslavia, Zambia, Austria, France, Pakistan, India, South Africa, Uganda, New South Wales, Netherlands, England and Wales, Argentina, Bosnia and Herzegovina, Italy.

${ }^{10}$ Ibid, paragraph 181 . The Chamber also expanded the definition of rape to include forced oral penetration, see De Brouwer, A.M. Supranational Criminal Prosecution of Sexual Violence: The ICC and the Practice of the ICTY and the ICTR (Intersentia Antwerpen - Oxford 2005), p. 113.

${ }^{11}$ International Criminal Tribunal for the former Yugoslavia, Rules of Procedure and Evidence, U.N. Doc. IT/32/Rev.7 (1996), entered into force 14 March 1994; International Criminal Tribunal for Rwanda, Rules of Procedure and Evidence, U.N. Doc. ITR/3/REV.1 (1995), entered into force 29 June 1995.

${ }^{12}$ International Criminal Court (ICC), Elements of Crimes, 2002, Article 7(1)(g)-1, Article 8(2)(b)(xxii)-1 and 8(2)(e)(vi)-1,

${ }^{13}$ Footnote 16, Elements of Crimes.

14 Rules of Procedure and Evidence of the International Criminal Court U.N. Doc. PCNICC/2000/1/Add.1 (2002). 
${ }^{15}$ Rule 72 Rules of Procedure and Evidence of the International Criminal Court U.N. Doc. PCNICC/2000/1/Add.1 (2002).

${ }^{16}$ Prosecutor v Kunarac, Kovac, Vukovic, Case No. IT-96-23\&23/1, Judgment (Feb. 22, 2001).

${ }^{17}$ Kunarac, paragraph 443-456. Jurisdictions surveyed by the Tribunal included: Bosnia and Herzegovina, Germany, Korea, China, Norway, Austria, Spain, Brazil, Sierra Leone, New York, Maryland, Massachusetts, Switzerland, Portugal, France, Italy, Denmark, Sweden, Finland, Estonia, Japan, Argentina, Costa Rica, Uruguay, Philippines, California, England and Wales, Canada, New Zealand, New South Wales, Victoria, India, South Africa, Zambia, Bangladesh, Pakistan, Belgium.

${ }^{18}$ Kunarac, paragraph 438.

${ }^{19}$ The Prosecutor v. Kunarac, (IT-96-23-T \& IT-96-23/1-T)-A, (June 12, 2002) paragraph 130.

${ }^{20}$ Prosecutor v Milutinovic et al Case No. IT-05-87-T (26 February 2009) paragraph 200; Prosecutor v Gacumbitsi, Case No. ICTR-2001-64-A, Appeals Chamber (7 July 2006) paragraph 147.

${ }^{21}$ The Prosecutor v. Jean-Pierre Bemba Gombo (ICC-01/0501/08) 21 March 2016, paragraph 105; The Prosecutor v. Germain Katanga (ICC-01/04-01/07-3436) 7 March 2014, paragraph 965.

${ }^{22}$ Law No. 06/18 and Law No. 06/19 of 2007 are explained in ACORD DRC, Protection and Reparation for Survivors of SGBV Under Congolese Law: Situational Analysis and Prospects for Reform (June 2010).

${ }^{23}$ Judgment, M.C. v. Bulgaria, Appl. No. 39272/98, 4 December 2003, paragraph 163.

${ }^{24}$ Council of Europe Treaty Series - No. 210, Explanatory Report to the Council of Europe Convention on preventing and combating violence against women and domestic violence, paragraph 193. Section 273.1(1) \& 265(3) Canadian Criminal Code and Section 74, 75 \& 76 
Sexual Offences Act 2003 are examples of mixed definitions of rape: include abusive instances such as where force, threats etc were used and a positive definition of consent.

${ }^{25} R P B v$ the Philippines, (Communication No. 34/2011) Committee on the Elimination of Discrimination against Women, 12 March 2014, paragraph 2.5.

${ }^{26}$ Footnote 68, Elements of Crimes.

${ }^{27}$ M.C. v Bulgaria, paragraph 166.

${ }^{28}$ Trial Transcript, Bemba Gombo (ICC-01/05-01/08-3343) 21 January 2011, page 36 and 44. Testimony of the male rape victim sheds important light on the issue of sexual violence as gendered and not solely perpetrated against females.

29 The Prosecutor $v$ Jean-Pierre Bemba Gombo (ICC-01/05-01/08) Decision on the Confirmation of Charges 15 June 2009 paragraph 179.

${ }^{30}$ Kunarac, paragraph 460.

${ }^{31}$ The ICTY made this point in Kunarac at paragraph 131 citing Germany, New Jersey (New Jersey v Martin, 235 N.J. Super. 47, 56, 561 A.2d, 631, 636 (1989)), and Columbia (Women Prisoners of the District of Columbia Department of Corrections v District of Columbia).

\section{References}

Amnesty International 'Stop Violence Against Women: How to use International Criminal Law to Campaign for Gender-Sensitive Law Reform’ 12 May 2005, Index number: IOR 40/007/2005.

Angiolini, E. 2015. Report of the Independent Review into The Investigation and Prosecution of Rape in London. April 2015.

Askin, K.D. 2003 'Prosecuting Wartime Rape and Other Gender-Related Crimes Under International Law; Extraordinary Advances, Enduring Obstacles' Berkeley Journal of International Law 21: 288-349. 
Bedont, B. and Hall Martinez, K. 1999 'Ending Impunity for Gender Crimes under the International Criminal Court’ The Brown Journal of World Affairs 6(1): 65-85.

Bergoffen, D. 2009 'Exploiting the Dignity of the Vulnerable Body: Rape as a Weapon of War’ Philosophical Papers 38(3): 307-325

Boon, K. 2001'Rape and Forced Pregnancy Under the ICC Statute: Human Dignity, Autonomy, and Consent’ Columbia Human Rights Law Review 32: 625-675

Brammertz, B.S. and Jarvis M. 2016. Prosecuting Conflict-Related Sexual Violence at the ICTY. Oxford: Oxford University Press.

Chappell, L. 2016. The Politics of Gender Justice at the International Criminal Court: Legacies and Legitimacy, Oxford: Oxford University Press.

Chappell, L. and Durbach, A. 2014. 'The International Criminal Court: A Site of Gender Justice? International Feminist Journal of Politics, 16(4): 533-537

Charlesworth, H. and Chinkin, C. 2000. The Boundaries of International Law A Feminist Analysis. United Kingdom: Manchester University Press.

Chinkin, C. (1995) 'Amicus Curiae Brief on Protective Measures for Victims and Witnesses’ Criminal Law Forum 7(1): 179-212.

Chinkin, C. 'Rape and Sexual Abuse of Women in International Law' (1994) 5 European Journal of International Law 5(1): 326-341

Clark, J.N. 2016. 'The First Rape Conviction at the ICC: An Analysis of the Bemba Judgment' Journal of International Criminal Justice 14(3): 667-687.

Cohen, D.K. 2013. “Explaining Rape during Civil War: Cross-National Evidence.” American Political Science Review 107(3): 461-77. 
Copelon, R. 2000-01. ‘Gender Crimes as War Crimes: Integrating Crimes against Women into International Criminal Law’ McGill Law Journal 46: 217-240

De Brouwer, A.M. 2009. 'What the International Criminal Court has Achieved and can Achieve for Victims/Survivors of Sexual Violence', International Review of Victimology 16(2): 189-209.

Engle, K. 2005 'Feminism and Its (Dis)contents: Criminalizing Wartime Rape in Bosnia and Herzegovina' (2005) The American Journal of International Law 99: 778-816.

Erez, E. and Sebba, L. 2013. 'From Individualization of the Offender to Individualization of the Victim' in The Criminology of Criminal Law edited by Freda Adler, William S. Laufer. New Brunswick: Transaction Publishers.

Fisher, K. 2012. Moral Accountability and International Criminal Law: Holding Agents of Atrocity Accountable to the World. London and New York: Routledge.

Estrich, S. 1987. Real Rape: How The Legal System Victimizes Women Who Say No. Cambridge: Harvard University Press.

García-Moreno, C. , Watts, C., Pallitto, C., Stöckl, H., DeVries, K., and Abrahams, N. 2013. Global and Regional Estimates of Violence Against Women: Prevalence and Health Effects of intimate partner violence and non-partner sexual violence. World Health Organisation.

Gekker, E. 2014. 'Rape, Sexual Slavery, and Forced Marriage at the International Criminal Court: How Katanga Utilizes a Ten-Year-Old Rule but Overlooks New Jurisprudence' Hasting's Women's Law Journal 25(1): 105-134. 
Gotell, L. 2008. 'Rethinking Affirmative Consent in Canadian Sexual Assault Law: Neoliberal Sexual Subjects and Risky Women’ Akron Law Review 41(4): 865-898.

Grewal, K. 2000 'Rape in Conflict, Rape in Peace: Questioning the Revolutionary Potential of International Criminal Justice for Women's Human Rights' The Australian Feminist Law Journal 33: 57-80

Grewal, K. 2012 'The Protection of Sexual Autonomy Under International Criminal Law: The International Criminal Court and the Challenge of Defining Rape' Journal of International Criminal Justice 10: 373-396

Grewal, K. 2015 'International Criminal Law as a Site for Enhancing Women’s Rights? Challenges, Possibilities, Strategies’ Feminist Legal Studies 23(2): 149-165.

Green, J., Copelon, R., Cotter, P., and Stephens, B. 1994 'Affecting the Rules for the Prosecution of Rape and Other Gender Based Violence Before the International Criminal Tribunal for the Former Yugoslavia: A Feminist Proposal and Critique' Hastings Women's Law Journal 5: 171-242

Halley, J. (2008-09) 'Rape at Rome: Feminist Interventions in the Criminalization of SexRelated Violence in Positive International Criminal Law’ Michigan Journal of International Law 30(1): 1-124

Henry, N. 2014 'The Fixation on Wartime Rape: Feminist Critique and International Criminal Law’ Social \& Legal Studies 14(3): 93-111

Horvath, M. and Woodhams, J. eds. 2013. Handbook on the Study of Multiple Perpetrator Rape: A Multidisciplinary Response to an International Problem. New York: Routledge International Criminal Court, The Office of the Prosecutor Report on Prosecutorial Strategy, 14 September 2006, available at https://www.icc-cpi.int/NR/rdonlyres/D673DD8C-D427- 
accessed 02/10/2016]

International Federation for Human Rights, 2013. DRC: Victims of Sexual Violence Rarely Obtain Justice and Never Receive Reparation: Major Changes Needed to Fight Impunity.

Kalosieh, A. 2003. 'Consent to Genocide?: The ICTY’s Improper Use of the Consent Paradigm to Prosecute Genocidal Rape in Foca’ Women’s Rights Law Reporter 24: 121-136.

Kapur, A. 2016. 'The Value of International-National Interactions and Norm Interpretation in Catalysing National Prosecution of Sexual Violence’ Onati Socio-Legal Series 6(1): 62-90.

Kouvo, S. and Pearson, Z. eds. 2011. Feminist Perspectives on Contemporary International Law: Between Resistance and Compliance. Oxford: Hart Publishing.

Kuo, P. (2002) 'Prosecuting Crimes of Sexual Violence in an International Tribunal' Case Western Reserve Journal of International Law 34(3): 305-321.

McGregor, J. 2005. Is it Rape?: On Acquaintance Rape and Taking Women's Consent Seriously. Aldershot, U.K.: Ashgate.

MacKinnon, C. 1994 ‘Rape, Genocide and Women’s Human Rights’ Harvard Women’s Law Journal 17: 5-16.

Marcus, M. 2013. 'Investigation of Crimes of Sexual and Gender-Based Violence Under International Criminal Law' in Sexual Violence as an International Crime: Interdisciplinary Approaches edited by De Brouwer, A.M., Ku, C., Römkens, R. and van den Herik, L. Chapter 12. Cambridge: Intersentia.

Meger, S. 2016 ‘The Fetishization of Sexual Violence in International Security’ International Studies Quarterly 60: 149-159. 
Munro, V. 2010. 'From Consent to Coercion: Evaluating International and Domestic Frameworks for the Criminalization of Rape' in McGlynn, C. and Munro, V. (eds) Rethinking Rape Law: International and Comparative Perspectives. Chapter 2. London: Routledge.

Munro, V.E. 2017. 'Shifting Sands? Consent, Context and Vulnerability in Contemporary Sexual Offences Policy in England and Wales’, Social \& Legal Studies 26(4): 417-440

Ní Aoláin, F. 2015 'Feminism Facing International Law’, European Journal of Women's Studies 22(4) 457-462.

Ní Aoláin, F. 2014 'Gendered Harms and their Interface with International Criminal Law: Norms, Challenges and Domestication’ International Feminist Journal of Politics 16(4): 622646.

Ní Aoláin, F. 1997 'Radical Rules: The Effects of Evidential and Procedural Rules on the Regulation of Sexual Violence in War’ Albany Law Review 60(3): 883-905.

O’Byrne, K. 2011. 'Beyond Consent: Conceptualising Sexual Assault in International Criminal Law’ International Criminal Law Review 11(3): 495-514.

O’Rourke, C. 2013. 'International Law and Domestic Gender Justice, or Why Case Studies Matter' in Feminist Perspectives on Transitional Justice: From International and Criminal to Alternative Forms of Justice edited by Fineman, M.A. and Zinsstag, E. Antwerp: Intersentia.

Pearce, J. 2013. 'A Social Model of “Abused Consent”' in Melrose, M. and Pearce, J. (eds) Critical Perspectives on Child Sexual Exploitation and Related Trafficking. Palgrave Macmillan.

Shahabuddeen. M. 2004. 'Does the Principle of Legality Stand in the Way of Progressive Development of Law?’ Journal of International Criminal Justice 2(4): 1007-1017. 
Spees, P. 2003. ‘Women’s Advocacy in the Creation of the International Criminal Court: Changing the Landscapes of Justice and Power' Signs: Journal of Women in Culture and Society 28(4): 123-54.

Temkin, J. and Krahe, B. 2008. Sexual assault and the justice gap: A question of attitude Oxford: Hart Publishing.

United Nations, 'Report of the Secretary-General on Conflict-Related Sexual Violence' 15 April 2017 (s/2017/249).

United Nations Commission on Human Rights. 1994. Preliminary report submitted by the Special Rapporteur on violence against women, its causes and consequences, Ms. Radhika Coomaraswamy, in accordance with Commission on Human Rights resolution 1994/45, E/CN.4/1995/42 22 November 1994.

Van Sliedregt, E and Vasiliev, S. (eds) 2014, Pluralism in International Criminal Law. Oxford: Oxford University Press.

Victim's Rights Working Group, The Impact of the Rome Statute System on Victims and Affected Communities, April 2010.

Wood, E. J. 2014. “Conflict-Related Sexual Violence and the Policy Implications of Recent Research” The International Review of the Red Cross 96(894): 457-78

Women’s Initiatives for Gender Justice 'Report on the 10-Year Review Conference of the Rome Statute and the International Criminal Court 31 May - 11 June 2010 Kampala, Uganda’ December 2010. 